Historic, Archive Document

Do not assume content reflects current scientific knowledge, policies, or practices. 



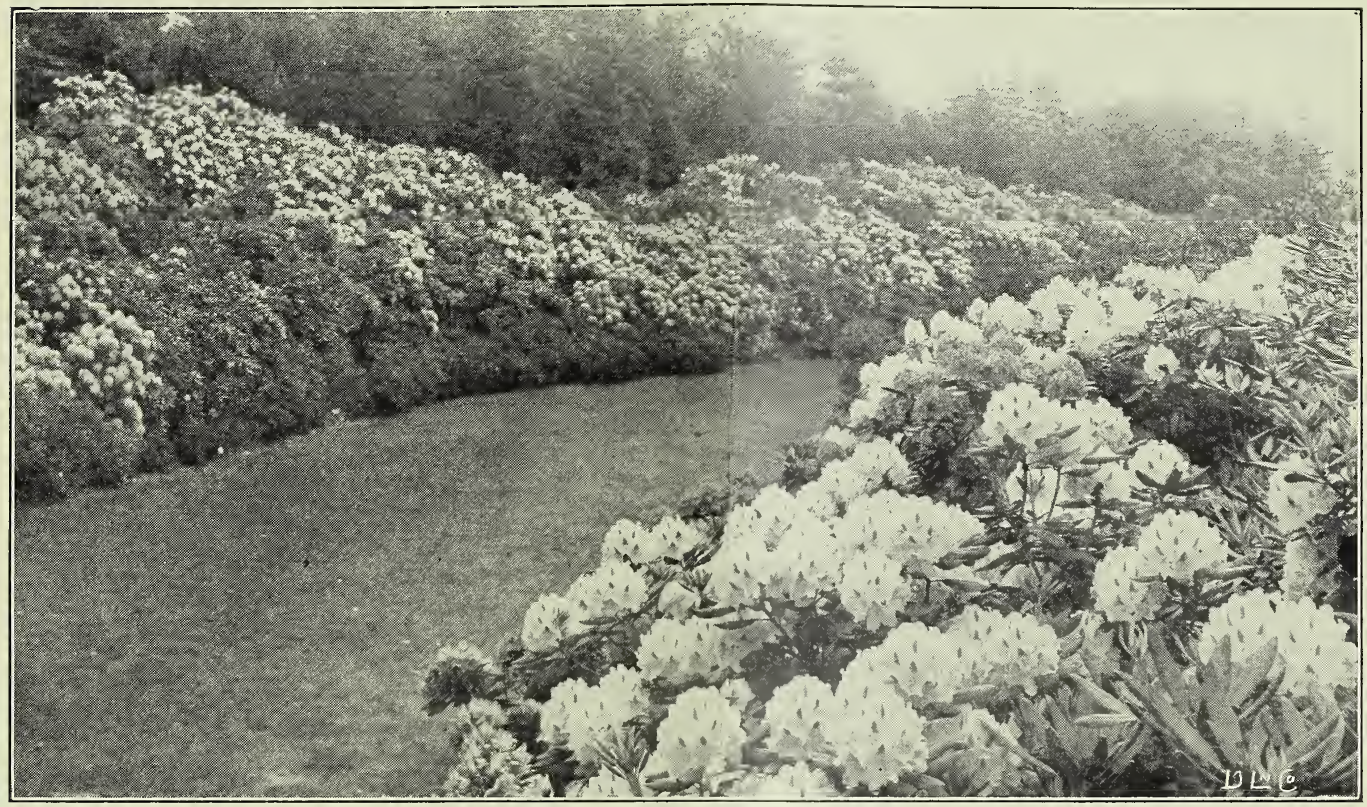

A PLANTING OF RHODODENDRONS

\section{RHODODENDRONS For Spring 1925}

It is useless to dwell upon the beauties of this magnificent evergreen shrub. All are familiar with its broad, glossy, dark green foliage and superb trusses of showy flowers of gorgeous tints and colors.

Culture.-They flower best in peat soil, and, like Azaleas, are most effective when grouped. In preparing a bed, if possible, locate where it will be partly sheltered from the intense heat in Summer and from cutting winds in Winter. The bed should be prepared with old sod, good leafmold or peat, which prevents the fine, hair-like roots from drying out in hot Summer weather, from which cause many plants are lost. Heavy mulching in Summer is an excellent preventive, and in dry weather the beds should be thoroughly watered. Pinch off all seed pods after flowering in order to get good buds for the next season. In Fall mulch the beds a foot or more with leaves, and if these can be left to decay, it is advisable to do so. Will not thrive if lime is in the soil.

Rhododendron and Kalmia latifolia are two of the best plants in the everg een line for grouping or planting under a border of large trees or shrubs, or planting in the woodland.

These are offered by the hundred of the various sizes.

If taken in carlots there will be no charge for packing.

If taken in less than carlots then there would be a charge for packing additional at cost.

Price is at point of shipment.

\section{RHODODENDRON MAXIMUM}

Color of flower light pink, shading to white. Collected in New York and Pennsylvania with ball.

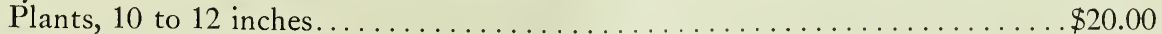

Plants, 12 to 18 inches....................................... 40.00

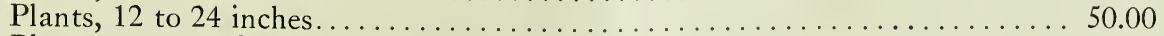

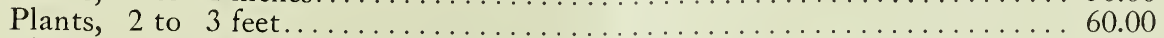

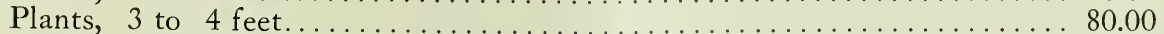

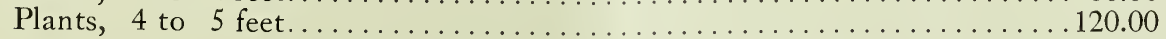




\section{RHODODENDRON MAXIMUM}

Collected plants in North Carolina. These plants are the finest plants to be found in this country.

Large specimen clumps dug with ball. Color light pink shading to white.

Per 100

Plants, 1 to 2 feet.

$\$ 80.00$

Plants, 2 to 3 feet. . . . . . . . . . . . . . . . . . . . . . . . . . . . . . 100.00

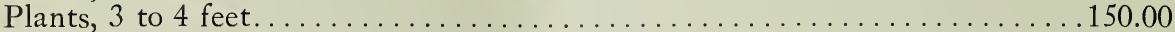

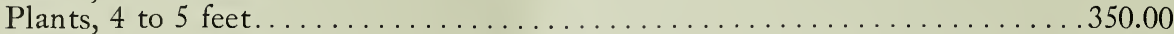

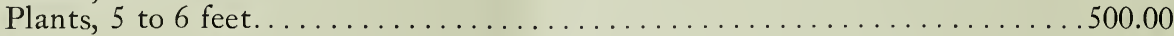

\section{RHODODENDRON CATAWBIENSE}

Collected in North Carolina. Very fine, extra selected strong clumps with ball.

Color of flower pink tinted with lavender. Very large flower. $\quad$ Per 100

Plants, 1 to 2 feet, selected, strong clumps with ball. . . . . . . . . . . . . . . \$120.00

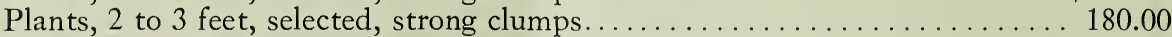

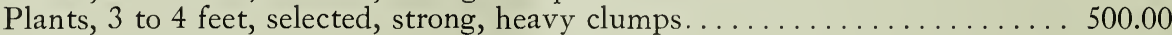

\section{RHODODENDRON CAROLINIANUM}

Collected in North Carolina.

These plants have a pink flower and are beautiful.

These are all selected, strong, heavy plants and dug with ball.

Per 100

Plants, 2 to 3 feet, strong, selected . . . . . . . . . . . . . . . . . . . . . . . . . . . \$200.00

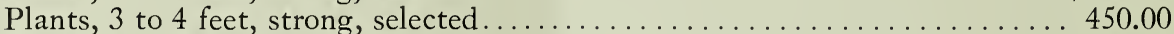

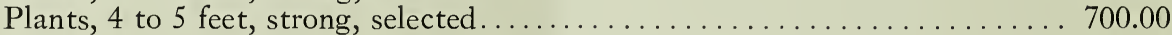

\section{KALMIA LATIFOLIA (Mt. Laurel)} plants.

Collected plants in carlots in New York and Pennsylvania states. First-class

Color of flower pink.

Per 100

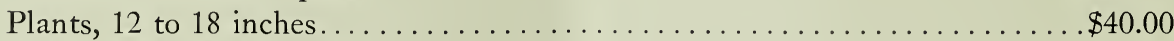

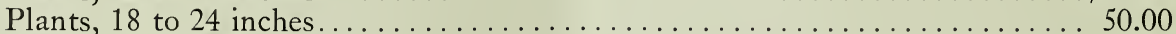

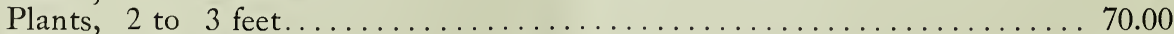

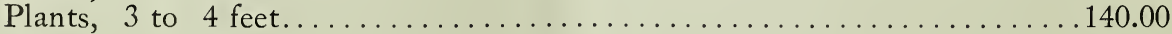

\section{KALMIA LATIFOLIA (Mt. Laurel)}

Collected in Virginia.

These are very large, heavy, selected specimen clumps and the very finest that grow in this country.

Dug with a good ball and ball burlapped.

Those wanting the very best plants in this line should purchase those growing in Virginia.

Per 100

Plants, 12 to 18 inches.

Plants, 18 to 24 inches............................................ 100.00

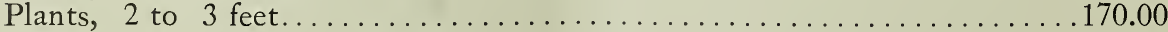

Plants, 3 to 4 feet. 


\section{AZALEAS in Variety}

Collected in North Carolina, and the plants are fine.

\section{AZALEA ARBORESCENS}

Bearing white or rosy blossoms late in Summer. Hardy and of easy culture.

Per 100

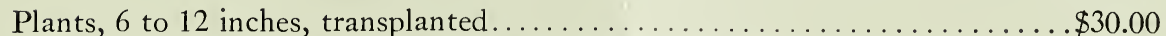

Plants, 1 to 2 feet, strong, transplanted, cut back clumps.............. 80.00

Plants, 1 to 2 feet, extra strong, transplanted, selected clumps. . . . . . . . . . 100.00

Plants, 2 to 3 feet, extra strong, transplanted, selected clumps.........Per 10, 30.00

Plants, 3 to 4 feet, extra strong, transplanted, selected clumps........Per $10,50.00$

\section{AZALEA CANESCENS (Rose Color)}

Per 100

Plants, 1 to 2 feet, extra selected, stocky clumps, balled and burlapped..... \$ \$120.00

Plants, 2 to 3 feet, extra selected, stocky clumps, balled and burlapped....... 150.00

\section{AZALEA LUTEA (Calendulacea)}

Flame Color

Per 100

Plants, 1 to 2 feet, extra grade clumps. . . . . . . . . . . . . . . . . . . . \$60.00

Plants, 2 to 3 feet, heavy, selected, compact, stocky clumps. . . . . . . . . . 100.00

Plants, 3 to 4 feet, heavy, selected, compact, stocky lumps. . . . . . . . . . . 180.00

\section{AZALEA NUDIFLORA (Pinxter)}

Color Pink or Red

Per 100

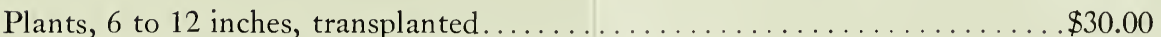

Plants, 1 to 2 feet, strong, transplanted, selected clumps............. 70.00

Plants, 1 to 2 feet, extra strong, transplanted, selected heavy clumps........ 90.00

\section{AZALEA VASEYI (Carolina Azalea)}

Per 100

Plants, 6 to 12 inches, transplanted.......................... $\$ 80.00$

Plants, 12 to 18 inches, strong, transplanted plants................... 100.00

Plants, 9 to 12 inches, extra strong, selected clumps................... 130.00

Plants, 12 to 18 inches, extra strong, transplanted clumps. . . . . . . . . . 160.00

\section{AZALEA VISCOSA}

\section{Small White Azalea}

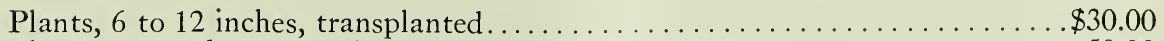

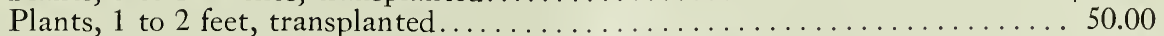

Plants, $1 \frac{1}{2}$ to 2 feet, transplanted clumps, well budded . . . . . . . . . 70.00 


\section{EVERGREENS}

\section{TSUGA CAROLINIANA (Carolina Hemlock)}

Seedlings collected in North Carolina. Per 100 6 to 12 inches, strong, transplanted............................ $\$ 35.00$

1 to 2 feet, strong, transplanted, balled and burlapped................. 170.00

2 to 3 feet, strong, transplanted, balled and burlapped............Per 10, 50.00

3 to 4 feet, strong, transplanted, balled and burlapped..............Per 10, 80.00

4 to 5 feet, strong, transplanted, balled and burlapped..............Per 10,100.00

\section{TSUGA CANADENSE (Hemlock)}

Collected

Grown in New York and Pennsylvania, in carlots. Per 100

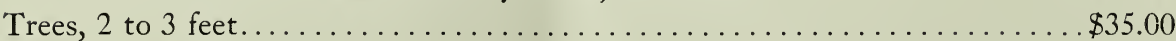

Trees, 3 to 4 feet.............................................. 60.00

Trees, 4 to 5 feet.......................................... 90.00

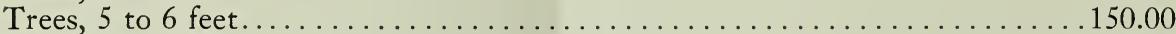

Trees, 6 to 8 feet.......................................... 200.00

Trees, 8 to 10 feet........................................... 3500

\section{BALLING AND BURLAPPING EVERGREENS}

Per tree additional

2 to 3 feet.

$\$ 0.10$

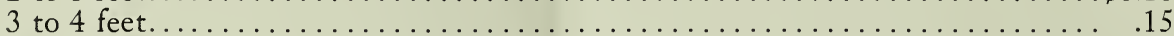

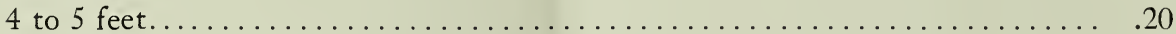

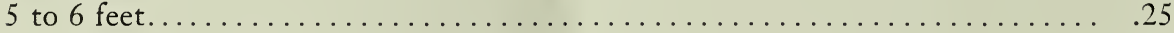

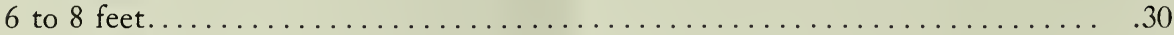

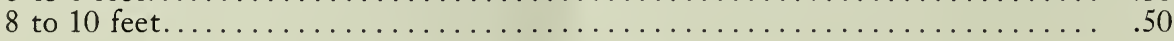

\section{APPROXIMATE NUMBER OF RHODODENDRONS AND KALMIA LATIFOLIA IN CAR}

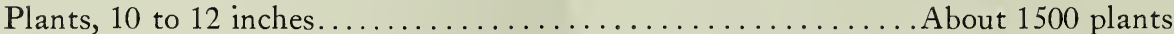

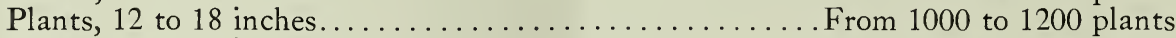

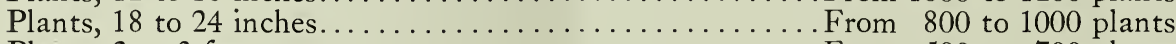

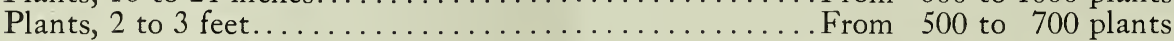

Plants, 3 to 4 feet................................ 300 to 400 plants

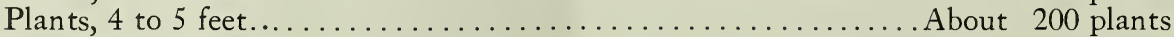

Plants, 5 to 6 feet.............................. 100 to 150 plants

The above is about the number that can be shipped in car.

All of the trees and plants are of good quality and in good condition, and offered at the above price until sold.

MORE THAN FORTY YEARS' EXPERIENCE IN COLLECTING AND SHIPPING RHODODENDRONS

As for other trees and plants, send list of wants for prices.

\section{THE MORRIS NURSERY COMPANY}

